\title{
PENGARUH TINGKAT SOLVABILITAS DAN PROFITABILITAS TERHADAP AUDIT DELAY PADA PERUSAHAAN DAGANG YANG TERDAFTAR DI BURSA EFEK INDONESIA TAHUN 2015-2019
}

\author{
Arnida Wahyuni Lubis, Ikhsan Abdullah \\ Prodi Akuntansi Fakultas Ekonomi dan Bisnis Islam UINSU \\ Prodi Akuntansi Fakultas Ekonomi dan Bisnis UMSU \\ Arnidawahyunilubis@gmail.com, Ihsanabdullah@umsu.ac.id
}

\begin{abstract}
This study wants to find out how much the level of solvency and profitability can affect the audit delay in trading companies on the IDX. The method used in this research is descriptive quantitative research that seeks to study and explain how an independent variable affects the dependent variable. The population and sample in this study were 47 companies, but 34 companies registered since 2015 - 2019 did not publish financial reports. There were 6 companies that suffered losses and did not use the rupiah currency using annual financial reports. a 5-year period of observation from 2015-2019, so that the total sample was 35 observations of data collection in this study, namely by using documentation data with the type and source of quantitative data obtained from www.idx.co.id. The data analysis technique used is multiple linear regression analysis. Based on the test results, it shows that the level of covability has an effect on the audit, while the profitability has no effect on the audit delay. But simultaneously the Level of Covability and Profitability has no effect on Audit Delay.
\end{abstract}

Keywords: Solvency Level, Profitability, Audit Delay.

\section{Pendahuluan}

Perusahaan yang terdaftar Bursa Efek Indonesia diwajibkan untuk membuat laporan keuangan setiap tahunnya yang telah di audit, paling lama 4 bulan sejak tanggal tutup buku kepada Bapepam. Hal ini sesuai dengan keputusan Ketua Bapepam-LK Nomor: KEP431/BL/2012, Penyampaian bahwa Laporan Tahunan Emiten Atau Perusahaan Publik terdaftar di Bursa Efek Indonesia (BEI) wajib untuk menyerahkan laporan keuangan auditor independennya kepada Bapepam-LK paling lambat 4 bulan dari tanggal laporan keuangan tahunan. Audit delay lamanya waktu penyelesaian audit diukur dari tanggal 31 Desember sampai tanggal tertera pada laporan audit independen.

Menurut (Subekti, I,. \& Widiyanti, 2016) keterlambatan publikasi akibat dari Audit Delay yang lama akan menyebabkan reaksi pasar yang negatif bagi perusahaan dan KAP. Oleh karena itu, auditor dituntut untuk mengurangi Audit Delay dalam menghilangkan citra buruk yang mungkin akan diterima perusahaan dan KAP. Namun permasalahan yang terjadi, banyaknya perusahaan tidak melaporkan keuangannya. Padahal Bei sudah memberikan kelonggaran untuk menyampaikan laporan keuangan tersebut.

Bisnis Com, Jakarta. Selasa (21/7/2020) Terdapat 80 perusahaan yang tidak menerbitkan laporan keuangan tahun 2019 secara tepat waktu ke Bapepam. BEI akan memberikan peringatan tertulis 1 atas keterlambatan tersebut, peringatan tertulis 2 dan denda Rp. 10 juta apabila mulai bulan ke 2 sampai dengan perusahaan tercatat tetap tidak 
memenuhi kewajiban penyampaian laporan keuangan. Peringatan tertulis 3 dan tambahan denda Rp. 30 juta jika pada bln ke 3jika tidak menyampaikan laporan keuangan. Suspensi pada bulan ke 4 jika emitem masih mangkir dari kewajiban BEI akan memberikan denda Rp. 150 juta.

Profitabilitas berpengaruh terhadap Audit Delay perusahaan. Menurut Mustikawati dan Saemargani (2015) profitabilitas yang dihitung berdasarkan rasio ROA (Retun On Assets), memang berpengaruh signifikan terhadap audit. Profitabilitas perusahaan yang tinggi waku audit delay nya cenderung singkat karena profitabilitas yang tinggi merupakan kabar baik sehingga perusahaan tidak akan menunda untuk mempublikasikan laporan keuangan perusahaan tersebut.

Tingkat Solvabilitas berpengaruh terhadap Audit Delay, karna Auditor perlu lebih teliti dalam proses audit karena tingginya utang akan mempengharui kerugian dan going concern perusahaan. Lianto \& Kusuma (2015) jika tingkat solvabilitas perusahaan semakin tinggi maka risiko keuangan perusahaan juga menjadi semakin tinggi. Oleh karena itu, dalam melakukan audit laporan keuangan, waktu yang dibutuhkan auditor lebih lama dan membuat audit Delay. perusahaan menjadi semakin panjang.

Berdasarkan latar belakang dan pengujian para penelitian diatas maka dapat peneliti tertarik mengambil judul pada penelitian ini adalah "Pengaruh Tingkat Solvabilitas dan Profitabilitas terhadap Audit Delay pada perusahaan Dagang yang terdaftar di BEI.

\section{Kajian Teori}

\subsection{Audit Delay}

Audit Delay merupakan senggang waktu antara tanggal pelaporan keuangan ke BEI dengan laporan keuangan akhir tahun yaitu 31 desember tahun berjalan. Dengan lamanya perusahaan melaporkan keuangan untuk dipublikasikan, maka akan berdampak buruk bagi perusahaan dan juga Kantor Akuntan Publik. Hal ini berdampak kepada saham perusahaan, investor mempunyai keraguan akan kondisi perusahaan.

Menurut Lestari (2010:28) audit delay menyebutkan audit delay sebagai rentang waktu penyelesaian laporan audit laporan keuangan tahunan, diukur berdasarkan lamanya hari yang dibutuhkan untuk memperoleh laporan keuangan auditor independen atas audit laporan keuangan perusahaan sejak tanggal tutup buku perusahaan, yaitu per 31 Desember sampai tanggal yang tertera pada laporan auditor independen.

Rumus :

Audit Delay $=$ Tanggal laporan audit - tanggal laporan keuangan

\subsection{Profitabilitas}

Arfan Ikhsan, dkk (2018, hal 97) Profitabilitas merupakan kemampuan yang dicapai oleh perusahaan dalam suatu periode tertentu. yang bertujuan untuk mengukur kemampuan perusahaan dalam menghasilkan laba.

Profitabilitas merupakan rasio yang di gunakan untuk melihat perbandingan anatara laba yang di peroleh terhadap total asset perusahaan. Semakin besar laba bersih maka semakin cepat perusahaan di dalam mempublikasikan laporkan keuangan tersebut dan sebalik nya, semakin kecil laba yang di peroleh, semakin lama perusahaan untuk mempublikasikan laporan keuangan nya. Hal ini di sebabkan laporan keuangan merupakan salah satu alat yang digunakan untuk melihat kondisi suatu perusahaan.

Rumus yang digunakan dalam penelitian ini adalah dengan menggunakan ROA, di hitung dengan cara membandingkan laba bersih yang tersedia untuk pemegang saham biasa dengan total aktiva.

$$
\begin{aligned}
& \text { Rumus : } \\
& \text { ROA }=\frac{\text { Laba bersih }}{\text { Total Aset }} \times 100 \%
\end{aligned}
$$




\subsection{Solvabilitas}

Suatu perusahaan selalu memiliki hutang untuk melaksakan aktivitas operasi perusahaan selain dari modal usaha. Jika suatu perusahaan aktivitas operasinya lebih besar dengan menggunakan hutang dari pada modal usahanya dan perusahaan tidak mampu membayarnya, maka kemungkinan perusahaan akan mengalami permasalahan didalam mengelolah usahanya tersebut.

Menurut Dermawan,dkk (2013, hal 37) rasio solvabilitas menggambarkan kemampuan perusahaan melunasi kewajiban jangka panjang apabila perusahaan dilikuidasi. Jika hutang nya besar maka beban bunga yang di bebankan ke perusahaan semakin besar. Rumus yang digunakan yaitu dengan menggunakan DER.

Eka Rahmawati (2017) yang menyatakan bahwa Solvabilitas berpengaruh terhadap Audit Delay.

Berikut rumus mencari DER adalah sebagai berikut :

$$
\text { DER }=\frac{\text { Total Hutang }}{\text { Ekuitas }} \times 100 \%
$$

\section{Kerangka Konseptual}

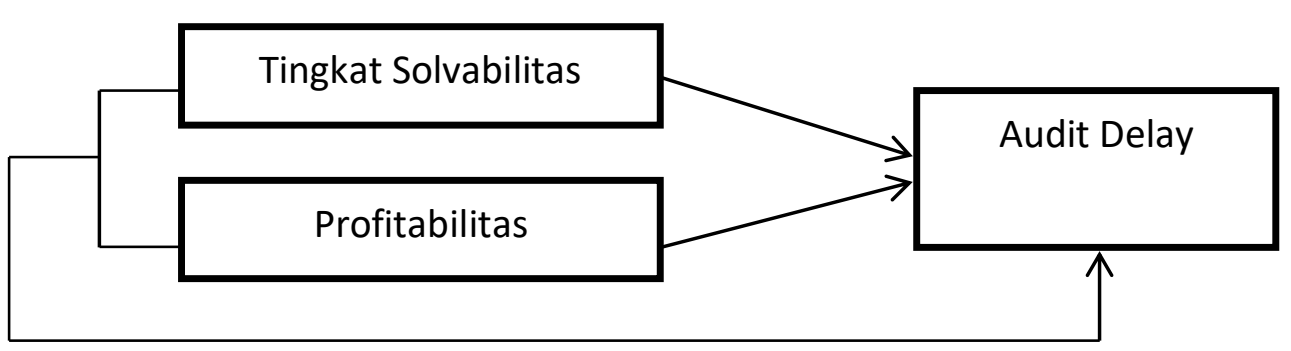

Gambar 2.1

Kerangka Konseptual

\subsection{Hipotesis Penelitian}

Berdasarkan masalah penelitian dan kerangka konseptual yang telah dikembangkan sebelumnya, maka dapat dirumuskan hipotesis sementara sebagai berikut :

a. Tingkat Solvabilitas berpengaruh terhadap Audit Delay

b. Profitabilitas berpengaruh terhadap Audit Delay

c. Tingkat Solvabilitas dan Profitabilitas berpengaruh terhadap Audit Delay

\section{Metode Penelitian}

Penelelitian ini menggunakan pendekatan asosiatif kuantitatif. Populasi pada penelitian ini adalah perusahaan Dagang yang terdaftar pada BEI dengan periode penelitian 5 tahun pengamatan mulai dari 2015 sampai dengan 2019 yang terdiri dari 7 perusahaan. Sampel penelitian diambil dengan menggunakan metode non-probability sampling dengan menggunakan teknik purposive sampling, Purposive sampling adalah teknik penentuan sampel dengan pertimbangan tertentu. Nilai setiap variabel pada penelitian ini bersumber pada laporan tahunan yang diperoleh dari situs BEI. Pada penelitian ini menggunakan analisis regresi linear berganda pada mengujian hasil akhir untuk menentukan pengaruh variabel independen terhadap variabel dependen (Ghozali,2013). Berikut model yang diguankan untuk menguji hipotesis penelitian ini adalah sebagai berikut :

$$
\mathrm{PL}=\mathrm{a}+\mathrm{b} 1 \mathrm{CR}+\mathrm{b} 2 \mathrm{DER}+\mathrm{b} 3 \mathrm{GPM}+\mathrm{b} 4 \mathrm{NPM}+\mathrm{b} 5 \mathrm{ROA}+\mathrm{e}
$$


Pada penelitian ini, dua tahap pengujian yang harus dilakukan yaitu tahap pertama uji analisis data, asumsi klasik yang terdiri dari uji normalitas, uji heterokedastisitas,uji multikolinearitas yang tujuannya untuk memastikan bahwa model regresi dan masingmasing variabel layak dilakukan uji hipotesis. Tahap kedua uji koefisien determinasi yang tujuan untuk mengetahui besarnya pengaruh variabel independen terhadap variabel dependen.

\section{Hasil dan Pembahasan}

\subsection{Hasil Penelitian}

1. UjiNormalitas

Hasil ujinormalitas dengan menggunakan analisisstatistik (One-Sample Kolmogorov Smirnov Test) menghasilkannilaiAsymp. Sig(2-Tailed) lebihdari 0,05. makaH0 diterimadan data berdistribusi normal.

Tabel 4.1

One-Sample Kolmogorov-Smirnov Test

\begin{tabular}{|ll|r|r|r|}
\hline & & TINGKAT & AUDIT DELAY \\
& & SOLVABILITAS & $\begin{array}{r}\text { PROFITABILIT } \\
\text { AS }\end{array}$ \\
\hline $\mathrm{N}$ & Mean & 35 & 35 & 35 \\
Normal Parameters & a,b & .9563 & 7.2851 & 69.3143 \\
& Std. Deviation & .60122 & 6.63692 & 11.85642 \\
& Absolute & .193 & .286 & .131 \\
Most Extreme Differences & Positive & .193 & .286 & .131 \\
& Negative & -.113 & -.190 & -.131 \\
Kolmogorov-Smirnov Z & & 1.140 & 1.694 & .777 \\
Asymp. Sig. (2-tailed) & & .149 & .006 & .581 \\
\hline
\end{tabular}

a. Test distribution is Normal.

b. Calculated from data.

Sumber :HasilPengolahan SPSS

Berdasarkandarihasil table uji K-S, dapatdilihatbahwabesarnyanilai K-S adalah (0.777) dan signifikan pada (0.581), maka hal ini menunjukkan bahwa data residual terdistribusi secara normal karena $>0.05$.

\section{UjiMultikolinearitas}

MenurutGhozali (2009) ujimultikolinearitas digunakan untuk menguji apakah dalam model regresidi temukan adanya korelasi antara variable bebas. Apabila ingin menguji adanya multikolinearitas dilihat dari nilai VIF (Variance Inflation Factor) atau nilai tolerance, jikanilaiVIF (Variance Inflation Factor) < 10, maka dapat disimpulkan data bebas dari gejala multikolinieritas. Hasil uji multikolinearitas ini dapatdilihat pada table berikut:

Tabel 4.2

\begin{tabular}{|c|c|c|c|c|c|c|c|}
\hline \multirow[t]{2}{*}{ Model } & \multicolumn{2}{|c|}{$\begin{array}{c}\text { Unstandardized } \\
\text { Coefficients }\end{array}$} & \multirow{2}{*}{$\begin{array}{c}\text { Standardized } \\
\text { Coefficients } \\
\text { Beta }\end{array}$} & \multirow[t]{2}{*}{$\mathrm{t}$} & \multirow[t]{2}{*}{ Sig. } & \multicolumn{2}{|c|}{$\begin{array}{l}\text { Collinearity } \\
\text { Statistics }\end{array}$} \\
\hline & $\mathrm{B}$ & Std. Error & & & & Tolerance & VIF \\
\hline (Constant) & 58.611 & 5.085 & & 11.527 & .000 & & \\
\hline TINGKAT SOLVABILITAS & 7.991 & 3.483 & .405 & 2.294 & .028 & .855 & 1.170 \\
\hline PROFITABILITAS & .420 & .316 & .235 & 1.332 & .192 & .855 & 1.170 \\
\hline
\end{tabular}

Berdasarkan hasil pengujian di atas diketahui nilai VIF variable tingkat solvabilitas (1.17), VIF variable Profitabilitas (1.17) ,karena nilai VIF untuk sema variable tersebut $<10$, maka dapat disimpulkan tidak terjadi gangguan multikolinearitas atau dengan kata lain model regresi ini terbebas dari gejala multikolinearitas 
3. UjiHeterokedastisitas

Hasil uji heterokedasitas dengan menggunakan unstandardardized residual yang tujuan untuk mengetahui hubungan ataukorelasi antar keempat variabelindependen menghasilkan nilaisiginifikanasi (Sig 2-tailed)lebihdari 0,05. Sehingga nilai dianggap korelasi lebih dari 0.05, maka ditarik kesimpulan bahwa pada model regresi ini tidak ditemukan adanya heterokedastisitas. Adapun hasil uji heterokedasitas adalah sebagai berikut:

Tabel 4.3

Uji Heterokedastisitas

Coefficients $^{\mathrm{a}}$

\begin{tabular}{|c|c|c|c|c|c|c|}
\hline \multirow{2}{*}{\multicolumn{2}{|c|}{ Model }} & \multicolumn{2}{|c|}{ Unstandardized Coefficients } & \multirow{2}{*}{$\frac{\text { Standardized Coefficients }}{\text { Beta }}$} & \multirow[t]{2}{*}{$\mathrm{t}$} & \multirow[t]{2}{*}{ Sig. } \\
\hline & & B & Std. Error & & & \\
\hline \multirow{3}{*}{1} & (Constant) & 58.611 & 5.085 & & 11.527 & .000 \\
\hline & $\begin{array}{l}\text { TINGKAT } \\
\text { SOLVABILITAS }\end{array}$ & 7.991 & 3.483 & .405 & 2.294 & .028 \\
\hline & PROFITABILITAS & .420 & .316 & .235 & 1.332 & .192 \\
\hline
\end{tabular}

Berdasarkanhasilpenolahan data spss diatas ditemukan bahwa nilai sigrifikansi (Sig) pada variable tingkatsolvabilitas (0.028) sedangkan nilai signifikansi (Sig) variable profitabilitas (0.192) maka data ini disimpulkan bahwa tidak terjadi gangguan asumsi heterokedastisitasartinya model regresi ini sudah baik. Hal ini juga dapat di lihat pada gambar berikut:

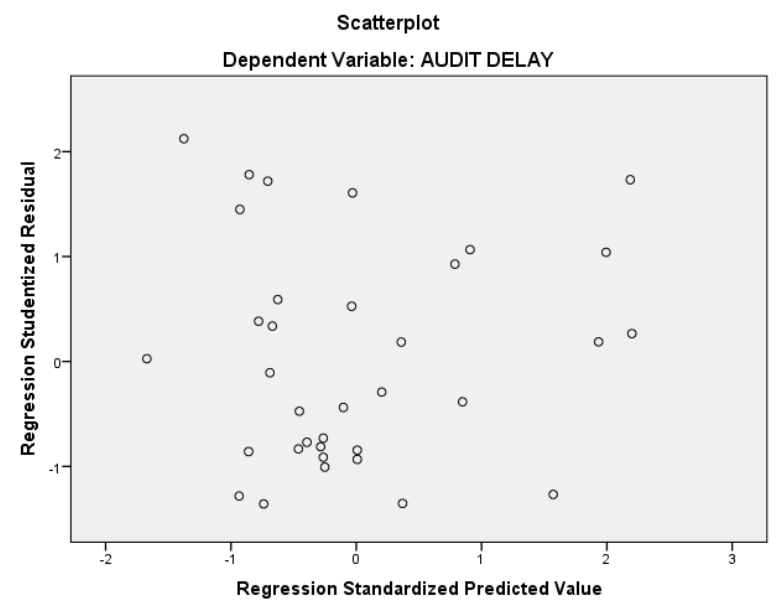

Gambar 4.1

Berdasarkan hasil pengujian diatas terlihat bahwa titik-titik data tidak membentuk pola tertentu dan data menyebar di atas dan di bawah angka 0 pada sumbu $\mathrm{Y}$, maka dari itu dapat disimpulkan bahwa tidak terjadi gangguan asumsi heterokedastisitas artinya model regresi ini sudah baik.

\section{b. UjiHopotesis}

Berdasarkan hasil dari pada perhitungan yang dilakukan peneliti dengan menggunakanaplikasi SPSS, maka diperoleh persamaan regresi linear berganda sebagai berikut :

$\mathrm{PL}=11.627+0,444 \mathrm{CR}+0,441 \mathrm{DER}-0,204 \mathrm{GPM}-0,121 \mathrm{NPM}-0,440 \mathrm{ROA}+\mathrm{e}$

Uji hipotesis regresi linear berganda ini digunakan untuk menguji kelayakan model persamaan regresi dan mengetahui apakah secara parsial variable indenpen berpengaruh secara signifikan terhadap variable dependen. 


\section{Koefisiendeterminasi}

Hasil pengujian pada koefisien determinasi $\left({ }^{R^{2}}\right) \quad(0,383)$ artinya bila dikalikan seratus persen maka kemampuan variable independennya menjelaskan variable dependen sebesar $38,3 \%$.

Tabel 4.4

Model Summary ${ }^{\mathrm{b}}$

\begin{tabular}{|l|r|r|r|c|}
\hline Model & \multicolumn{1}{|c|}{$\mathrm{R}$} & R Square & $\begin{array}{c}\text { Adjusted R } \\
\text { Square }\end{array}$ & $\begin{array}{c}\text { Std. Error of the } \\
\text { Estimate }\end{array}$ \\
\hline 1 & $.383^{\mathrm{a}}$ & .147 & .094 & 11.28826 \\
\hline
\end{tabular}

a. Predictors: (Constant), PROFITABILITAS , TINGKAT SOLVABILITAS

b. Dependent Variable: AUDIT DELAY

Berdasarkan hasil pengolahan data spss di atas di temukan bahwa variable $\mathrm{X}$ dalam menjelaskan variable $\mathrm{Y}$ hanya sebesar $38.3 \%$.Sisanya sebesar $61,7 \%$ dijelaskanoleh variable lain di luarmodel. Hasil yang terbaik adalah mendekati nilai sebesar $100 \%$.

Tabel 4.5

ANOVA $^{\mathrm{a}}$

\begin{tabular}{|rl|r|r|r|r|r|}
\hline Model & & Sum of Squares & \multicolumn{1}{|c|}{ Df } & Mean Square & F & Sig. \\
\hline \multirow{3}{*}{1} & Regression & 701.951 & 2 & 350.976 & 2.754 & $.079^{\mathrm{b}}$ \\
& Residual & 4077.591 & 32 & 127.425 & & \\
& Total & 4779.543 & 34 & & & \\
\hline
\end{tabular}

a. Dependent Variable: AUDIT DELAY

b. Predictors: (Constant), PROFITABILITAS, TINGKAT SOLVABILITAS

\section{Uji Goodness of Fit (F)}

Berdasarkan nilai output di atas nilai Sig.(0.05) > (0.79) maka variable Tingkat solvabilitas dan variable Profitabilitas secara simultan tidak berpengaruh terhadap variable Audit Delay. Dari table uji F diperoleh nilai F sebesar (2.754) dengan nilai signifikan sebesar(0,79) sehingga dapat ditarik kesimpulan bahwa secara simultan kedua variable independent tidak mempunyai pengaruh yang signifikan terhadap variable dependen.

\section{Ujiparsial (uji t)}

Tabel 4.6

4. Coefficients ${ }^{\mathrm{a}}$

\begin{tabular}{|c|c|c|c|c|c|c|}
\hline \multirow{2}{*}{\multicolumn{2}{|c|}{ Model }} & \multicolumn{2}{|c|}{ Unstandardized Coefficients } & \multirow{2}{*}{$\begin{array}{c}\text { Standardized } \\
\text { Coefficients }\end{array}$} & \multirow[t]{2}{*}{$\mathrm{t}$} & \multirow[t]{2}{*}{ Sig. } \\
\hline & & $\mathrm{B}$ & Std. Error & & & \\
\hline \multirow{3}{*}{1} & (Constant) & 58.611 & 5.085 & & 11.527 & .000 \\
\hline & TINGKAT SOLVABILITAS & 7.991 & 3.483 & .405 & 2.294 & .028 \\
\hline & PROFITABILITAS & .420 & .316 & .235 & 1.332 & .192 \\
\hline
\end{tabular}

a. Dependent Variable: AUDIT DELAY

Pada uji ini, nilai variable tingkat solvabilitas (0.028) mempunyai pengaruh yang signifikan terhadap Audit Delay karena memiliki nilai signifikansikurang dari 0,05 sedangkan pada nilai variable profitabilitas (0.192) tidak mempunyai pengaruh yang signifikan karena lebih besar dari 0,05 terhadap Audit Delay.

\subsection{Pembahasan}

Berdasarkan penelitian yang telah dilakukan, diperoleh hasil pengaruh Tingkat Solvabilitas dan Profitabilitas terhadap audit Delay adalah sebagai berikut :

\section{Pengaruh Tingkat Sovabilitas Terhadap Audit Delay}

Dari hasil penelitian yang dilakukan, bahwa tingkat solvabilitas berpengaruh terhadap Audit Delay. Semakin kecil tingkat rasio ini maka semakin mudah perusahaan untuk melaporkan keuangan ke BEI dan jika sebaliknya perusahaan akan semakin lama untuk mempubliksikan laporan keuangan. karna jika semakin besar hutang yang dimiliki 
suatu perusahan maka berpengaruh terhadap investor untuk yakin menanamkan modalnya keperusahaan tersebut dan berdampak ke going concern perusahaan tersebut.

Syafrida Hani (2015, hal 124) semakin tinggi Debt to Equity Ratio (DER)menunjukan bahwa komposisi total hutang semakin besar dibandingkansehinggah berdampak semakin besar beban perusahaan terhadap kreditur hal ini di sebabkan karna akan terjadi beban bunga atas manfaat yang di peroleh dari kreditur.

\section{Pengaruh Profitabilitas terhadap Audit Delay}

Dari hasil penelitian yang dilakukan, bahwa Profitabilitas tidak berpengaruh terhadap Audit Delay didalam penelitian ini. Tingkat pangaruh nya lebih kecil sehinggah hasil olah data profitabilitas tidak berpengaruh.

Arfan Ikhsan, dkk (2018, hal 97) Profitabilitas merupakan kemampuan yang dicapai oleh perusahaan dalam suatu periode tertentu. yang bertujuan untuk mengukur kemampuan perusahaan dalam menghasilkan laba. Rasio yang digunakan didalam penelitian ini dengan menggunakan ROA.

Hal ini tidak sesuai dengan penelitian Kartika (2009) bahwa profitabilitas memiliki pengaruh terhadap audit delay. Ada beberapa alasan yang mendorong terjadi nya kemunduran laporanpublikasi yaitu pelaporan laba ataurugi sebagai indikator good news dan bad news atas kinerja menejerial perusahaan dalam setahun.

\section{Pengaruh Tingkat Solvabilitas dan Profitabilitas terhadap Audit Delay}

Berdasarkan hasil penelitian pada tabel menunjukkan bahwa Tingkat Solvabilitas (X1) dan Profitabilitas $\left(\mathrm{X}_{2}\right)$ secara bersama-sama atau simultan tidak memiliki pengaruh yang signifikan terhadap Audit Delay (Y). hal ini dikernakan kecilnya pengaruh Profitabilitas terhadap Audit Delay pada hasil penelitian ini sehinggah secara simultan tidak berpengaruh.

\section{Kesimpulan dan Saran \\ 5.1 Kesimpulan}

Berikut kesimpulan yang dapat ditarik dari hasil penelitian antara lain sebagai berikut

1. Tingkat Solvabilitas mempunyai pengaruh yang signifikan terhadap Audit Delay. DER merupakan Rasio yang digunakan untuk mengukur kemampuan perusahaan didalam kemampuannya membayar utang jangka panjangnya. Semakin kecil rasio ini maka semakin cepatlah perusahaan untuk mempublikasikan laporan keuangan nya kemasyarakat melalui BEI, semakin besar hutang besar rasio hutang maka perusahaan semakin lama untuk menyelesaikan laporan keuangannya untuk dipublikasikan ke BEI.

2. Profitabilitas tidak mempunyai pengruh yang besar terhadap Audit Delay didalam penelitian ini. ROA merupakan rasio yang digunakan untuk mengukur kemampuan perusahaan didalam menghasilkan laba.

3. Tingkat Sovabilitas dan Profitabilitas secara simultan tidak berpengaruh didalam penelitian ini

\subsection{Saran}

1. Diharapkan para perusahaan dagang yang terdaftar di BEI agar secepatnya mempublikasikan laporan keuangannya agar tidak kena teguran dan sangsi oleh Bapapem . investor juga bisa berfikiran negatif perusahaan dan Kantor Akuntan Publik tersebut.

2. Pada penelitian selanjutnya diharapkan bisa dilakukan dengan mengeksplorasi faktor-faktor lain yang mempengaruhi Audit Delay selain dari Tingkat Solvabilitas dan dan Profitabilitas. 


\section{Referensi}

Azizah, Nur dan Kumala Sari. 2012. Pengaru Profitabilitas, Rasio Hutang, Ukuran Perusahaan dan Jenis perusahaan terhadap Audit Report Lag. Amik Raharja Informatika Tanggerang

Arfan Ikhsan, dkk (2018) analisa Laporan Keuangan, Medan. Madenatera

Bapepam. (2012). Keputusan Ketua BAPEPAM-LK Nomor KEP-431/BL/2012 tentang Penyampaian Laporan Keuangan Tahunan Emiten atau Perusahaan Publik. Otoritas Jasa Keuangan

Darmwan Syahrial, dkk (2013) Analisis laporan keuangan, Jakarta Mitra Wacana media

Eka Rahmawati. 2017. Analisis Faktor-Faktor yang mempengaruhi Audit Delay (Studi Empiris Pada Perusahaan Manufaktur yang Tercatat di Bursa Efek Indonesia Tahun 2013-2015). Universitas Negeri Yogyakarta. Universitas Muhammadiyah Surakarta.

https://market.bisnis.com/read/20200721/7/1269043/80-emiten-terlambat-terbitkan-laporankeuangan-2019.

Kartika, Andi. 2009. "Faktor-Faktor yang Mempengaruhi Audit Delay di Indonesia (Studi Empiris pada Perusahaan-perusahaan LQ45 yang terdaftar di Bursa Efek Jakarta). Jurnal Bisnis dan Ekonomi (JBE), Hal. 1-17. Vol. 16, No. 1

Lianto, N., \& Kusuma, H. (2015). Faktor-Faktor Yang Berpengaruh Terhadap Audit Report Lag. 4(3), 40-47

Lestari, D. (2010). Analisis Faktor-Faktor yang Mempengaruhi Audit Delay: Studi Empiris pada Perusahaan Consumer Goods yang terdaftar di Bursa Efek Indonesia. Skripsi. Fakultas Ekonomi dan Bisnis Universitas Diponegoro, Semarang.

Mustikawati, Indah. dan Fitria Ingga Saemargani. 2015. Pengaruh Ukuran Perusahaan, Solvabilitas, Ukuran KAP, dan Opini Auditor Terhadap Audit Delay. Jurnal Nominal/Volume IV Nomor 2. Prodi Akuntansi Universitas Negeri Yogyakarta.

Subekti,I dan Widiyanti, N,W (2016) "Faktor - factor yang mempengharuhi Audit Delay di Indonesia, In Simposium Nasional Akuntansi VII

Syaprida Hani (2015) Teknik Analisa Laporan Keuangan, Medan. UMSU Press 